\title{
Letter from the President
}

It is with great pleasure that the Society for American Music and Cambridge University Press jointly launch a new journal devoted to the study of American music. Only a few decades ago, American music topics were ignored, or if acknowledged, appeared as the unexpected article in more mainline journals or were relegated to the corners of conference programs. Within the past three decades, American music's status has changed dramatically. It has grown in size and its presence is secure and stable; what had been activity on the periphery is now squarely in the center. As someone who came of age in the 1960s, I have been able to share in the challenge and the excitement of this burgeoning field. Today it is especially gratifying to witness sophisticated American music scholarship emerging from many continents. Dissertations, books, articles, and papers are being written on American music by scholars throughout the world.

At SAM we believe that the community is ready for a new journal focusing on American music, one that is dedicated to the highest standards of scholarship. We are especially pleased to have partnered with Cambridge University Press in this endeavor. As the place of American music has changed, so has the world of musicology. New topics, new perspectives, new repertoires, and new methodologies energize our thinking. The field itself is beginning to enjoy a new reflexive relationship, not only reaching out to other disciplines for insights and approaches but contributing to them as well. Old disciplinary walls have fallen. Musicologists, ethnomusicologists, theorists, historians, and cultural studies practitioners have much in common, and the synergy of many points of view within a single forum will make JSAM a journal for the twenty-first century. JSAM will take risks, and by so doing will encourage a climate that challenges and stimulates intellectual debate. Because no music is offlimits, I suspect that we will need to develop new ways of talking about it. At SAM we also believe that the term American needs to extend far beyond the borders of the United States to embrace music in many areas of the Americas. JSAM will be in the forefront of all of these developments.

The world of publishing itself is undergoing seismic change, and we are honored to team with Cambridge, a leader in the exploration of new ideas and publishing technology. None of us can really predict what the digital world will look like ten years from now, but undoubtedly new means and opportunities will be available, and with Cambridge I believe our journal will be able to take full advantage of the possibilities that technology and new thinking allow. Already, Cambridge's resources will allow us to break the silence that constrains so many musical publications, where notes may stare up from the page but a myriad of musical details are lost. This is an especially thorny issue when dealing with much American music, which did not originate in score. JSAM will also be one of the first musicological journals to publish in color, as readers will see in this very issue. 
Our society looks forward to a long and fruitful relationship with Cambridge as we work together to bring our musics, our ideas, and our passion to an ever-growing audience of readers and listeners.

Michael Broyles 